\title{
Nutrition related knowledge and practices of hypertensive adults attending hypertensive clinics at day hospitals in the Cape Metropole
}

H Becker, (M.B.Ch.B.), Department of Human Nutrition, University of Stellenbosch M Bester, (M.B.Ch.B.), Department of Human Nutrition, University of Stellenbosch N Reyneke, (M.B.Ch.B.), Department of Human Nutrition, University of Stellenbosch D Labadarios, (M.B.Ch.B.), Department of Human Nutrition, University of Stellenbosch

KD Monyeki, (Ph.D), CDL Unit, South African Medical Research Council

NP Steyn (Ph.D), CDL Unit, South African Medical Research Council

\section{Abstract}

The aim of this study was to determine nutrition knowledge and dietary practices of hypertensive adults attending hypertensive clinics at Day Hospitals in the Cape Metropole. Ten Day Hospitals were randomly selected from a total of 31 Day Hospitals and the first participants attending the hypertension clinics per day were recruited. A total of 85 participants were evaluated. The weight, height, waist and hip circumference of each participant was measured, as well as their blood pressure. Knowledge of dietary intake was obtained by completing a questionnaire, during an interview with the patient. Knowledge regarding salt usage indicated that a large percentage $(34.1 \%)$ of participants believed that flavour enhancers like Aromat or Fondor could safely be used instead of table salt. Furthermore, $23.5 \%$ reported that linned and smoked meat or fish have a low sodium (salt) content. Fruit and vegetables were perceived as having a positive effect on hypertension by $74.1 \%$ of participants. However, only $15 \%$ of the group knew that the recommendation for their usage was five or more servings per day. Only $12.9 \%$ of participants in this study had a normal weight (body mass index (BMI) $<25$ ), $25.9 \%$ were overweight (BMI 25 - 29.9) and 61.2\% were obese ( $\mathrm{BMI} \geq 30$ ); $84.7 \%$ recognized the association between obesity and hypertension. A large waist circumference (>88 cm in women; $102 \mathrm{~cm}$ in men) was found in $61.2 \%$ of participants, however, only $18.2 \%$ of black men had such a measurement. Uncontrolled blood pressure readings ( $>140 / 90 \mathrm{~mm} \mathrm{Hg}$ ) were found in $61.2 \%$ of these patients at the hypertension clinics.

\section{Opsomming}

Die doel van hierdie studie was om dieetkennis en praktye van volwassenes met hipertensie wat hipertensieklinieke by die Daghospitale in Kaapstad bywoon, te bepaal. Tien uit 31 Daghospitale in Kaapstad is ewekansig geselekteer, en die eerste pasiënte wat die klinieke bygewoon het op die dag van besoek is gewerf. 'n Totaal van 85 pasiënte is geëvalueer. Die gewig, lengte, middel- en heupomtrek van elke deelnemer is gemeet, asook hulle bloeddruk. Kennis omtrent dieetinname is verkry deur middel van 'n vraelys wat gedurende 'n onderhoud met die pasiënt voltooi is. Kennis in verband met soutverbruik het getoon dat 'n hoë persentasie $(34.1 \%)$ deelnemers geglo het dat Aromat of Fondor veilig gebruik kan word in plaas van tafelsout. Verder het $23.5 \%$ gerapporteer dat ingemaakte en gerookte vleis of vis 'n lae natrium (sout) inhoud bevat. Vrugte en groente is deur $74.1 \%$ beskou as voedsel wat 'n positiewe effek op bloeddruk het, alhoewel slegs $15 \%$ van die groep het geweet dat vyf of meer porsies per dag benodig word. Slegs $12.9 \%$ van die deelnemers het 'n normale gewig gehad (liggaamsmassa indeks (LMI) < 25), terwyl 25.9\% oorgewig (LMI 25 - 29.9), en 61.2\% vetsugtig was (LMI $\geq 30$ ); $84.7 \%$ was bewus van die verhouding tussen vetsug en bloeddruk. ' $n$ Groot middelomtrek ( $>88 \mathrm{~cm}$ in vroue; $102 \mathrm{~cm}$ in mans) is by $61.2 \%$ pasiënte aangetref, alhoewel slegs $18.2 \%$ swart mans so 'n omtrek gehad het. Onkontroleerde bloeddruk (>140/90 mm Hg) is in $61.2 \%$ pasiënte aangetref. 


\section{Introduction}

Hypertension is the most commonly reported chronic illness among all SouthAfricans and results in end-organ damage such as heart failure, stroke and renal disease (Opie, 1995:37). People with hypertension have 2 to 3 times the risk of coronary heart disease and 7 times the risk of stroke (Castelli, 1983:1191). Among South Africans 15 years and older, the prevalence of hypertension is highest in white males (38\%) followed by Asian men (29.9\%) and lowest in black rural adults; 18.6 and $21.2 \%$ for men and women respectively (Department of Health, 2002:212).

Hypertension poses a health and economic burden on South Africans by virtue of its morbidity, costly complications, and predisposition to premature mortality (Daniels, Biesma, Otten Levitt, Steyn, Martell \& Dick, 2000:1210). Future increases can be anticipated among black South Africans, particularly in older black women where obesity is a predisposing risk factor. Hypertension among blacks is not caused by any inherent ethnic differences since previously the incidence of hypertension was low among rural blacks. However the process of urbanization appears to have increased the risk of hypertension considerably (Opie, 1995:44).

Factors that are implicated in the development and poor management of hypertension are numerous and include: weight gain; high dietary salt intake; low rennin status and salt sensitivity; tobacco use; insulin resistance; high alcohol intake and increased psychosocial stress levels (Opie, 1995:46).

One of the concerns with regard to patients with hypertension is the finding that many patients do not manage and control their blood pressure optimally. This requires both adherence to a healthy lifestyle and the regular use of prescribed blood pressure medication. There are many reasons for a lack of blood pressure control, with some of these being attributed to social and economic factors (Hale, Fritz \& Eales, 1998:453). Patients frequently do not return to the health-care centers for follow-up visits as a result of the costs incurred by transport and the time involved. A further consideration may be a lack of knowledge of the disease and its outcomes, in particular the risk of stroke. Daniels et al., (2000:1206) attributed poor service delivery as also being a major factor, which contributes to poor control of blood pressure in patients at primary health-care level.

It is known that quality of health care is dependent upon the knowledge, attitudes and practices of both physicians and health-care workers. One of the critical roles of primary health care in the management of blood pressure and prevention of stroke is education of the patient. Health-care professionals at all levels should be involved and should continually reinforce the message that stroke can largely be prevented by the control of blood pressure and by maintaining a satisfactory body weight and following a healthy lifestyle (Daniels et al., 2000:1206). A healthy lifestyle includes having a diet, which is low in sodium, high in fruit and vegetables and low in fat. The extent of patients' knowledge and practices with regard to a healthy diet for hypertension is unknown and a recent survey of the elderly in West Coast fishing villages (Charlton, Schloss, Visser, Lam- bert, Kolbe \& Levitt., 2001:149), found that 24-hour urinary sodium excretion corresponded to a dietary intake of about $9 \mathrm{~g}$ of salt per day, which exceeds the recommended value of $6 \mathrm{~g}$ or less per day of the US National High Blood Pressure Education Program (1997:2446). In the present study we attempted to identify the dietary knowledge and practices of patients relating to their hypertension and to their weight status.

\section{Methods Study design}

A cross-sectional descriptive study design was used in order to obtain health-related information from hypertensive patients in the Cape Metropole area.

\section{Sample}

This study was undertaken as a pilot study in order to select the best dietary questions to be used in a future collaborative urban study with Johns Hopkins University to investigate barriers to hypertension in black, "coloured" and white patients in Cape Town Metropole Day Hospitals in 2003. Ten Day Hospitals were randomly drawn from a total of 31 Day Hospitals in the Cape metropolitan area. The Day Hospitals were first stratified into hospitals which predominately service black, "coloured" and white patients respectively. Five hospitals were then randomly selected from each group. The Day Hospitals serve patients with no private medical aid, thus the participants come mainly from low and middle socio-economic classes.

The sample included four Day Hospitals (Brown's Farm, Cross Roads, Vanguard and Michael Mapongwana) which serviced mainly black patients and 6 Day Hospitals (Belhar, Reeds, Kensington, Strand and Hanover Park) which serviced mainly "coloured" and white patients. At each hospital in the sample the first patients attending the "hypertension clinic" at that hospital during the third week in January, were invited to participate in the study. There was a $100 \%$ response rate, and a sample of 85 patients with age ranging from 35 to 65 years participated in the study. The mean age of black female patients was $50.9(5.9)$ years and that of black males $56.7(8.8)$ years. The mean age of white and "coloured" females was $54.2(8.2)$ years and that of males 56.5 (7.4) years.

\section{Data collection}

A team of fieldworkers comprising three nurses and six fieldworkers undertook the fieldwork which comprised interviews, anthropometric and blood pressure measurements of the participants. The assessments were undertaken in co-operation with the nursing sister in charge of each hypertensive clinic.

The questionnaire was developed in consultation with 3 dietary experts (experienced dietitians), 2 nursing sisters and a specialist (M.B.Ch.B) in chronic diseases of lifestyle. These experts were required to identify essential knowledge concepts and questions, in order to provide construct, face and content validity to the questionnaire (Talmage \& Rasher, 1981:84). Dietary questions were se- 

attending Hypertensive Clinics at Day Hospitals in the Cape Metropolitan area

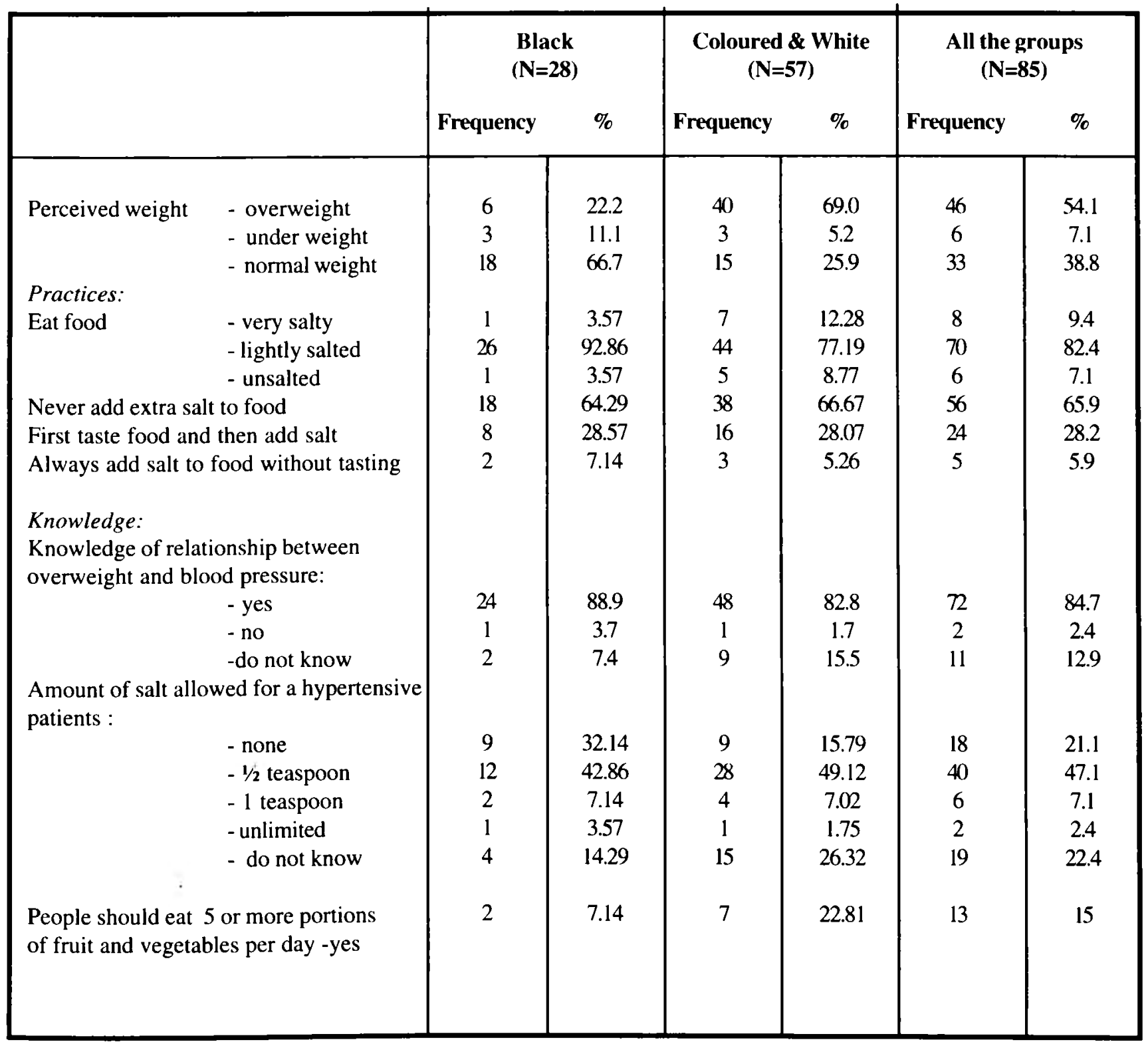

lected based on the following knowledge concepts which had been selected by the researchers as important aspects for patients to know: foods high and low in salt, foods high in fat; foods high in potassium; relationship of salt and blood pressure; relationship of obesity and hypertension. Additionally practices with regard to salt usage were also questioned, such as the addition of salt to food.

The questionnaire was piloted on 10 hypertensive adults attending a hypertensive clinic excluded from the sample hospitals. The participants included ones with various levels of education, ranging from primary school to graduates. The questionnaire was adapted after the testing phase in order to rectify dietary questions, which were nor clear or were found to be inappropriate.

\section{Measurements}

The weight, height, waist and hip circumference of each participant was measured, as well as his or her blood pres- sure. Anthropometric measurements and testing procedures used have been described by Monyeki, Toriola, de Ridder, Kemper, Steyn, Nthangeni, Twisk, and van Lenthe (2002:39). The absolute and relative values for intra-tester and intertester technical error of measurements (TEM\%) were calculated and comprised less than $2 \%$ of error. Procedural and quality control indicated a general adequate reproducibility across the broad range of measurements.

Height was measured with a stadiometer to the nearest centimetre and weight was measured with an electronic digital scale to the nearest kilogram. Hip and waist circumferences were measured using a flexible steel tape to the nearest centimeter, according to procedures of the International Society for the Advancement of Kinanthropometry (ISAK) (Norton \& Olds, 1996:398). Blood pressure and heart rate were measured with an Omron M4-I. Three measurements were taken with a two to five minute interval between measurements. The first measurement was then discarded and an average of the second two measurements was taken. 


\begin{tabular}{|c|c|c|c|c|c|c|}
\hline & \multicolumn{2}{|c|}{$\begin{array}{c}\text { Black } \\
(\mathbf{N}=\mathbf{2 8})\end{array}$} & \multicolumn{2}{|c|}{$\begin{array}{c}\text { Coloured \& White } \\
\qquad(\mathrm{N}=57)\end{array}$} & \multicolumn{2}{|c|}{$\begin{array}{l}\text { All the groups } \\
(\mathrm{N}=85)\end{array}$} \\
\hline & Frequency & $\%$ & Frequency & $\%$ & Frequency & $\%$ \\
\hline Fried egg & 3 & 10.71 & 6 & 10.53 & 9 & 10.6 \\
\hline Fruit \& Vegetables & 25 & 89.29 & 56 & 98.25 & 81 & 95.3 \\
\hline Pastries & 1 & 3.57 & 3 & 5.26 & 4 & 4.7 \\
\hline Chocolate & 3 & 10.71 & 3 & 5.26 & 6 & 7.1 \\
\hline Tinned/smoked meat & 5 & 17.86 & 16 & 28.07 & 21 & 24.7 \\
\hline Samp \& beans & 17 & 60.71 & 41 & 71.93 & 58 & 68.2 \\
\hline Mabella porridge & 19 & 67.86 & 42 & 73.68 & 61 & 71.8 \\
\hline Stock cubes & 5 & 17.86 & 15 & 26.32 & 20 & 23.5 \\
\hline Cheese \& cheese spreads & 14 & 50 & 26 & 45.61 & 40 & 47.1 \\
\hline Potato chips & 3 & 10.71 & 8 & 14.04 & 11 & 12.9 \\
\hline Liver & 13 & 46.43 & 26 & 45.61 & 39 & 45.9 \\
\hline Brown bread & 28 & 100 & 56 & 98.25 & 84 & 98.8 \\
\hline Tinned or packet soup & 8 & 28.57 & 28 & 49.12 & 36 & 42.4 \\
\hline Bovril & 7 & 25 & 20 & 35.09 & 27 & 31.8 \\
\hline Isidudu (soft maize) & 19 & 67.86 & 43 & 75.44 & 62 & 72.9 \\
\hline Vetkoek & 3 & 10.71 & 11 & 19.3 & 14 & 16.5 \\
\hline Fondor/Aromat & 3 & 10.71 & 14 & 24.56 & 17 & 20.0 \\
\hline Samoosa & 1 & 3.57 & 0 & 0 & 1 & 1.2 \\
\hline
\end{tabular}

\section{Statistical analyses}

Data was entered into spreadsheets in Excel (2000) and analyzed using the SPSS (2001) programme. Data was expressed in contingency tables designed to compare results between the groups. For the purpose of this study black patients have been placed in a category of their own. This is mainly because their dietary habits differ from those of the other two groups.

\section{Ethical issues}

The Ethics Committee of the University of Stellenbosch approved the research proposal. Informed written consent was obtained from all the participants

\section{Results}

\section{Dietary Practices}

Ninety-two percent of black participants and $77 \%$ of coloured and whites reported eating their food lightly salted (Table 1). More than $60 \%$ indicated that they do not add additional salt at the table and less than $10 \%$ reported adding salt to food without tasting it first.

\section{Dietary knowledge}

Knowledge regarding salt usage and its relationship to hypertension was better than we anticipated, except that less than $50 \%$ knew the amount of salt recommended for patients with hypertension. Foods perceived to be healthy by black patients (Table 2) in order of frequency, were: brown bread, fruit and vegetables, followed by mabella, soft maize porridge and samp and beans. For "coloured" and white patients fruit, vegetables and brown bread were most commonly cited, followed by soft maize porridge, maltabella, samp and beans. Very few patients regarded pastries, samosas and chocolates as healthy choices. However $24.7 \%$ thought tinned, smoked meat $(24.7 \%)$, chips (12.9\%) and Aromat/Fondor (20\%) were healthy options.

In Table 3 salt knowledge is tested in another format. It is promising to note that fruit and vegetables are perceived as having a positive impact on hypertension by $74.1 \%$ and use of herbs being used to flavor foods instead of salt by $69.4 \%$. Not so promising is the large percentage participants $(34.1 \%$ ) believing that Aromat/Fondor can be used instead of salt and that tinned cured meat and fish have a low salt content $(23.5 \%)$. 


\begin{tabular}{|l|c|c|c|c|c|c|}
\hline & \multicolumn{2}{|c|}{$\begin{array}{c}\text { Black } \\
\text { (N=28) }\end{array}$} & \multicolumn{2}{c|}{$\begin{array}{c}\text { Coloured \& White } \\
\text { (N=57) }\end{array}$} & \multicolumn{2}{c|}{$\begin{array}{c}\text { All the groups } \\
\text { (N=85) }\end{array}$} \\
& Frequency $\%$ & Frequency & Frequency & $\%$ \\
Fresh fish is high in salt** & 7 & 25 & 6 & 10.53 & 13 & 15.3 \\
$\begin{array}{l}\text { People with HBP can use Aromat/Fondor } \\
\text { in stead of salt** }\end{array}$ & 3 & 10.71 & 26 & 45.61 & 29 & 34.1 \\
S tock cubes do not contain salt** & 6 & 21.43 & 6 & 10.53 & 12 & 14.1 \\
Vegetables \& fruit can reduce your BP* & 25 & 89.29 & 38 & 66.67 & 63 & 74.1 \\
$\begin{array}{l}\text { Tinned, cured and smoked meat and fish } \\
\text { have a low salt content** }\end{array}$ & 7 & 25 & 13 & 22.81 & 20 & 23.5 \\
$\begin{array}{l}\text { Herbs can be used to flavor foods in- } \\
\text { stead of salt* }\end{array}$ & 13 & 46.43 & 46 & 80.7 & 59 & 69.4 \\
\hline
\end{tabular}

* This statement is actually true.

** This statement is actually false.

\section{Education on diet}

The most interesting finding in Table 4 is that $71.4 \%$ of black participants had received dietary information at the Hypertension Clinic compared with only $35.1 \%$ of white and "coloured" patients. There is a large difference between the two groups with regard to the source of dietary information: $53.6 \%$ of black patients had received dietary information from a nurse and none from a dietitian, while $3.5 \%$ and $12.3 \%$ of other patients had received dietary information from a nurse and dietitian respectively.

\section{Anthropometry}

Only $12.9 \%$ of participants in this study had a normal BMI $(<25), 25.9 \%$ were overweight and $61.2 \%$ were obese (Table 5). It was noted that $84.7 \%$ of the sample recognized the association between obesity and hypertension (Table 1). High waist measurements were found in $61.2 \%$ of the participants, but to a far lesser extent in black men (18.2\%). A high diastolic measurement was found in $45.8 \%$ of patients and a high systolic measurement in $57.6 \%$. Sixty-one percent of participants had a blood pressure above 140/ $90 \mathrm{mmHg}$.

\section{Discussion}

One of the main objectives of this study was to develop and test dietary questions relating to treatment of hypertensive patients. This has led to a further refining of the questionnaire which will now be used in a representative urban sample investigating barriers to treatment and management of hypertensive patients in Cape Town (started in
August 2003).

The national Demographic and Health Survey (Department of Health, 2002:215) found that in the Western Cape 5.1\% of males and $3.1 \%$ of females add salt before tasting their food and $15.5 \%$ of males and $10.5 \%$ of females reported that they eat their food very salty (Department of Health, 2002:217). Similar results were found in the participants of this study with $5.9 \%$ reporting that they always add salt to food before tasting it and $9.4 \%$ reported eating very salty food.

Knowledge of diet and hypertension was found to be rather poor, particularly with regard to quantification of salt intake as well as the number of fruits and vegetables to be consumed daily. An intake of at least five portions ( $400 \mathrm{~g}$ ) of fruit and vegetables per day is recommended as a healthy guideline for adults in terms of their contribution to potassium intake (Love \& Sayed, 2001:24). In the present study only $15 \%$ of participants knew that fruit and vegetable consumption should be at least five or more servings per day. In Cape Town it has been reported that $29 \%$ of black adults (aged 15-64 years) reported eating no vegetables or fruits in the previous 24-hour period (Bourne et al., 1994:147). This finding is most probably the result of poor socioeconomic status in a large proportion of blacks residing in Cape Town, which may impact negatively on their purchasing ability.

Knowledge regarding types of food considered to be healthy was generally good with brown bread and fruit and vegetables featuring very prominently as healthy food items. Furthermore, patients generally knew about the association between diet and obesity and about salt and hypertension. However, the high prevalence of obesity and uncon- 

professional at the Hypertensive Clinics at Day Hospitals in the Cape Metropolitan area

\begin{tabular}{|c|c|c|c|c|c|c|}
\hline & \multicolumn{2}{|c|}{$\begin{array}{c}\text { Black } \\
(\mathrm{N}=28)\end{array}$} & \multicolumn{2}{|c|}{$\begin{array}{c}\text { Coloured \& White } \\
(\mathrm{N}=57)\end{array}$} & \multicolumn{2}{|c|}{$\begin{array}{l}\text { All the groups } \\
(\mathbf{N}=85)\end{array}$} \\
\hline & Frequency & $\%$ & Frequency & $\%$ & Frequency & $\%$ \\
\hline $\begin{array}{l}\text { Been informed about } \\
\text { - reduced salt diet } \\
\text { - reduced fat diet } \\
\text { Received information from the Hyperten- } \\
\text { sive Clinic about diet } \\
\text { Who gave most dietary information at } \\
\text { the Clinic } \\
\text {-- doctor } \\
\text { - nurse } \\
\text { - dietician } \\
\text { - other }\end{array}$ & $\begin{array}{l}20 \\
15 \\
0 \\
2\end{array}$ & $\begin{array}{c}10.71 \\
53.57 \\
0 \\
7.14\end{array}$ & $\begin{array}{l}9 \\
2 \\
7 \\
2\end{array}$ & $\begin{array}{c}15.79 \\
3.51 \\
12.28 \\
3.51\end{array}$ & $\begin{array}{c}12 \\
17 \\
7 \\
4\end{array}$ & $\begin{array}{c}14.1 \\
20.0 \\
8.2 \\
4.7\end{array}$ \\
\hline
\end{tabular}

trolled blood pressure leads one to believe that many patients do not have a healthy diet. It is however acknowledged that other lifestyle risk factors, such as tobacco, inactivity and stress also have contributed to this situation (Steyn, Gaziano, Bradshaw, Laubscher \& Fourie 2001:1723). There is some evidence to suggest that hypertension in black South Africans, as in their African-American counterparts, is often salt sensitive (Touyz, Milne \& Reinach 1993:693; Worthington, Wendt \& Opie, 1993:296; Opie, 1995:38). Further, potassium intake has been shown to be low in both hypertensive and normotensive black subjects (Charlton, Steyn, Zulu, Jonathan, Levitt, Nel \& Veldman, 2002:12).

From the findings in this pilot study it appears that the majority of black patients received dietary advice from the clinic, while this was not the case for the rest of the participants, since only $35 \%$ reported receiving advice there. Furthermore, most black participants perceived nurses to be the main dietary advisers while "coloured" and white patients reported that doctors were. All in all however, more than $60 \%$ of patients had been informed about a reduced salt and/or low salt diet. Since we did not ask the health professionals at the clinics visited about the type of dietary advice, which they provide, it is difficult to assess the quality of the advice given. However, this appears to be an important focus area for future research on hypertensive patients and we recommend that this aspect be investigated.

Black patients are mainly receiving dietary advice from nurses at the clinics hence intervention tools for health promotion need to be developed to assist the clinic staff in empowering patients to consume a diet which is low in sodium and high in potassium. It is recommended that the health services develop and test culturally appropriate dietary educational tools.

\section{Acknowledgements}

We thank our fieldworkers and the participants of the study. We also gratefully acknowledge the co-operation of the nursing staff at the Day Hospitals partaking in the study.

\section{References}

BOURNE, I ; LANGENHOVEN, M; STEYN, K; JOOSTE, PL \& LAUBSCHER, JA 1994: The food and meal pattern in the black population of the Cape Peninsula. The BRISK Study. Central African Journal of Medicine. 40(6): 140-148.

CASTELLI, WP 1983: Cardiovascular disease and multifactorial risk: challenge of the 1980s. American Heart Journal, 106:1191-1200.

CHARLTON, KE; SCHLOSS, I; VISSER, M; LAMBERT, EV; KOLBE, T \& LEVITT, NS 2001: Waist circumference predicts clustering of cardiovascular risk factors in older South Africans. South African Cardiovascular Journal. 12(3):142-150.

CHARLTON, KE; STEYN, K; ZULU,J; JONATHAN, D; LEVIT,T NS; NEL, JH VELDMAN D 2002: Association between blood pressure and sodium, potassium and calcium excretion in South Africans. South African Journal of Clinical Nutrition. 15(3) Supplement 1:S12. (Abstract).

DANIELS, A; BIESMA, R; OTTEN, J; LEVITT, NS; STEYN, K; MARTELL, R \& DICK, J 2000: Ambivalence of primary health-care professionals towards the South African guidelines for hypertension and diabetes. South African Medical Journal. 90(12): 1206-1211. 


\begin{tabular}{|c|c|c|c|c|c|}
\hline & \multicolumn{2}{|c|}{$\begin{array}{l}\text { Black } \\
(\mathrm{N}=\mathbf{2 8})\end{array}$} & \multicolumn{2}{|c|}{$\begin{array}{c}\text { Coloured \& White } \\
\qquad(\mathrm{N}=57)\end{array}$} & \multirow{2}{*}{$\begin{array}{l}\text { All the groups } \\
\begin{array}{l}N=85 \\
n(\%)\end{array}\end{array}$} \\
\hline & $\begin{array}{l}\text { Males } \\
\mathrm{N}=11 \\
\mathrm{n}(\%)\end{array}$ & $\begin{array}{c}\text { Females } \\
\mathbf{N}=16 \\
n(\%)\end{array}$ & $\begin{array}{l}\text { Males } \\
N=13 \\
n(\%)\end{array}$ & $\begin{array}{c}\text { Females } \\
N=16 \\
n(\%)\end{array}$ & \\
\hline $\begin{array}{l}\text { Been informed about } \\
\text { Normal } \\
\text { Above cut-off }(>140 \mathrm{mmHg}) \\
\text { Hypertension Diastole: } \\
\text { Normal } \\
\text { Above cut-off }(>90 \mathrm{mmHg}) \\
\text { Hypertension }(>140 / 90 \mathrm{mmHg}) \\
\text { Waist circumference: } \\
\text { Normal } \\
\text { Above cut-off* } \\
\text { Waist to hip ratio: } \\
\text { Normal } \\
\text { Above cut-off** } \\
\text { Obesity: } \\
\text { Normal BMI } \\
\text { BMI between } 25-29.9 \\
\text { BMI above } 30 \\
\text { Total overweight (BMI } \geq=25)\end{array}$ & $\begin{array}{l}2(18.2) \\
9(81.2) \\
\\
4(36.4) \\
7(63.6) \\
4(36.4)\end{array}$ & $\begin{array}{l}9(56.3) \\
7(43.8) \\
\\
7(43.8) \\
9(56.3) \\
10(62.5)\end{array}$ & $\begin{array}{l}4(30.8) \\
9(69.2) \\
\\
9(69.2) \\
4(30.8) \\
9(69.2)\end{array}$ & $\begin{array}{l}21(46.7) \\
24(53.3) \\
\\
26(57.8) \\
19(42.2) \\
29(64.4)\end{array}$ & $\begin{array}{l}36(42.4) \\
49(57.2) \\
\\
46(54.1) \\
39(45.8) \\
52(61.2) \\
\\
33(38.8) \\
52(61.2) \\
51(60) \\
34(40) \\
11(12.9) \\
22(25.9) \\
52(61.2) \\
74(87.1)\end{array}$ \\
\hline
\end{tabular}

DEPARTMENT OF HEALTH 2002: South Africa Demographic and Health Survey. Pretoria: Department of Health.

HALE, LA; FRITZ, VU \& EALES, CJ 1998: Do stroke patients realise that a consequence of hypertension is stroke? South African Medical Journal. 88(4):45 1-454.

LOVE, P \& SAYED, N 2001: Eat plenty of vegetables and fruits everyday. South African Journal of Clinical Nutrition. 14(3):S24-S31.

MONYEKI, KD; TORIOLA, AL; DE RIDDER, JH; KEMPER, HC; STEYN, NP; NTHANGENI, ME; TWISK, JW \& VAN LENTHE FJ 2002: Stability of somatotypes in 4 to 10 year-old rural South African girls. Annals of Human Biology. 29(1):37-49.

NATIONAL HIGH BLOOD PRESSURE EDUCATION PROGRAM (NHBPEP) 1997: The sixth report of the Joint National Committee on Prevention, Detection, Evaluation, and Treatment of High Blood Pressure. Archives of Internal Medicine. 157:2413-2446.

NORTON, K \& OLDS, T 1996: Anthropometrica. Sydney: University of New South Wales Press, pp. 396-410.

OPIE, LH 1995: Hypertension. In. Fourie, J. \& Steyn ,K. (eds). Chronic Diseases of Lifestyle in South Africa.
Tygervalley: MRC Technical Report

STEYN, K; GAZIANO, TA; BRADSHAW, D; LAUBSCHER, R \& FOURIE, JM 2001: Hypertension in South African adults: results from the Demographic and Health Survey, 1998. Journal of Hypertension. 19(9): 17171725.

TALMAGE, H \& RASHER, SP 1981: Validity and reliability issues in measurement instrumentation. Journal of $\mathrm{Nu}-$ trition Education. 13:83-85.

TOUYZ, RM; MILNE, FJ \& REINACH,SG 1993: Racial differences in cell membrane ATPases and cellular cation content in urban South African normotensive and hypertensive subjects. American Journal of Hypertension. 6:693700.

WORTHINGTON, MG; WENDT, MC \& OPIE, LH 1993: Sodium transport in hypertension: assessment of membrane-associated defects in South African black and white hypertensives. Journal of Human Hvpertension. 7:291-297. 